\title{
A STUDY OF TRAPPED DUST AND DUSTFALL SAMPLES FROM HUMAN SETTLEMENTS NEAR REHABILITATED AND NON-REHABILITATED ABANDONED ASBESTOS MINE DUMPS IN THE NORTHERN CAPE PROVINCE, SOUTH AFRICA
}

\author{
TLOU B. MASHALANE ${ }^{1}$, SHADUNG J. MOJA ${ }^{1,2}$, OBED NOVHE $^{1}$, \\ MAPHUTI G. KWATA ${ }^{1,2}$ \& KHUTHADZO MASINDI ${ }^{1,2}$ \\ ${ }^{1}$ Water and Environment, Applied Geosciences, Council for Geoscience, South Africa \\ ${ }^{2}$ Department of Environmental Sciences, Florida Campus, University of South Africa, South Africa
}

\begin{abstract}
Abandoned asbestos mine dumps continue to have an effect on human health notwithstanding the banning of asbestos mining in South Africa in 2002. Asbestos mine dumps, especially non-rehabilitated dumps, contribute to dust pollution. Dust particles from these mine dumps find their way to nearby human settlements and cause health risks. Respiratory health issues such as lung diseases are a result of inhaled asbestos fibres/dust suspended in the air. For the purpose of environmental remediation, rehabilitated and non-rehabilitated sites around Kuruman and Prieska in the Northern Cape Province were selected to compare the presence of asbestos and the effectiveness of rehabilitation. Dustfall within a radius of $5.0 \mathrm{~km}$ from the asbestos mine dump to the nearest human settlement was measured and monitored. Characterisation was done for both trapped dust and dustfall samples. Dustfall samples were collected and measured using a $2.0 \mathrm{~m}$ stand with a single open bucket half-filled with deionised or distilled water. Trapped dust samples were collected indoors and outdoors from photo frames, window frames, old furniture and roof tops using sticky tape. The mineralogical composition of both indoor and outdoor samples was determined by X-ray diffraction (XRD). Mineralogical and morphological characterisation was further validated using scanning electron microscopy with energy dispersive spectroscopy (SEM-EDS). The XRD results show significant amounts of the amphibole $\left[\mathrm{Ca}_{2}(\mathrm{Fe}, \mathrm{Mg})_{5} \mathrm{Si}_{8} \mathrm{O}_{22}(\mathrm{OH})_{2}\right]$ asbestos mineral group. Trace amounts of the serpentine $\left[\mathrm{Mg}_{3} \mathrm{SiO}_{5}(\mathrm{OH})_{4}\right]$ asbestos mineral group were detected by XRD but could not be confirmed by SEM-EDS. However, both XRD and SEM-EDS results confirmed the presence of the amphibole asbestos mineral group. Other silicate minerals detected include quartz, talc, mica, plagioclase and feldspar. Detected nonsilicate minerals include calcite, smectite and traces of haematite. Exposure of asbestos minerals within human settlements continues to be a major health concern and sample characterisation substantiates the amount or levels and composition of the minerals.
\end{abstract}

Keywords: asbestos mine dump, asbestos fibres, dustfall, trapped dust, composition, characterisation, $X R D, S E M-E D S$.

\section{INTRODUCTION}

South Africa is a country with a large mineral capacity and output in its economy takes place through the mining sector. Hart [1] documented that in the 1930s asbestos mining was introduced in the country and negatively affected the environment and people's health. McCulloh [2] reported that around 1944 crocidolite $\left[\mathrm{Na}_{2} \mathrm{Fe}_{5}\left[(\mathrm{OH}) \mathrm{Si}_{4} \mathrm{O}_{11}\right]^{2}\right.$, a member of the amphibole asbestos group, was discovered in Australia and South Africa. In addition, about $97 \%$ of crocidolite asbestos was mined in South Africa, the world's eminent producer, and the remaining crocidolite was mined in Western Australia. Hart [1] reported that chrysotile $\left[\mathrm{Mg}_{3} \mathrm{SiO}_{5}(\mathrm{OH})_{4}\right]$ and amosite $\mathrm{MgFe}_{6}\left[(\mathrm{OH}) \mathrm{Si}_{4} \mathrm{O}_{11}\right]^{2}$ asbestos associated with serpentine were mined in the Mpumalanga and Limpopo Provinces. The crocidolite asbestos belt spans approximately $450 \mathrm{~km}$ from Prieska to Postmasburg and Kuruman along the Botswana 
border (Fig. 1). Asbestos products were preferred for their quality and durability and were mostly used for brake and clutch pads, electrical insulation and roofing. Human settlements in close proximity to non-rehabilitated asbestos dumps have high potential rates of exposure to windblown dust, which causes major health effects and environmental degradation. Inhalation of suspended asbestos fibres in the atmosphere cause respiratory problems, i.e. lung diseases. Instances of mesothelioma in the Northern Cape were discovered by Wagner [3]. McCulloh [2] and Hart [1] noted that continuous exposure of five or more years to asbestos could lead to progressive and untreated diseases, e.g. asbestosis, which could be exacerbated in smokers. Diseases associated with asbestos were further explained by Felix et al. [4] as lung cancer, asbestosis and mesothelioma. The risk of asbestos related diseases and exposure was not known during those times. No legislation had been implemented in South Africa during the time of asbestos mining, which disadvantaged the rights and deteriorated the health of people exposed to asbestos, especially miners and millers. The purpose of this study is to compare the presence of asbestos from rehabilitated and non-rehabilitated mine dumps and the effectiveness of rehabilitation. This was done by measuring, monitoring and analysing the concentration of dustfall samples and characterising trapped dust samples.

\section{STUDY AREA AND METHODOLOGY}

\subsection{Study area}

This research work was conducted in the Northern Cape Province near the towns of Kuruman and Prieska. Sites A and B within human settlements that are near asbestos mine dumps were selected for monitoring rehabilitated and non-rehabilitated dumps respectively (Fig. 1). Samples were collected during the dry periods of 2016 (i.e. June, July, and August). The area is characterised by steep to moderately steep mountains with upper to lower lying valleys (Fig. 2). Geologically, the study area forms part of the Asbestos Hills Subgroup of the Transvaal Supergroup in the Griqualand West basin containing significant amounts of iron present in superior type banded iron formations (Moore et al. [5]). The Asbestos Hills Subgroup spans from Prieska to the Botswana border, forming the prominent asbestos and Kuruman hills (Fig. 1). In addition, Moore et al. [5] documented that these successions form the upper part of the Late Archaean to Early Proterozoic Ghaap Group (Transvaal Supergroup) of the Griqualand West Basin.

Present Precambrian sediments probably belong to the iron-rich succession of the Daniëlskuil Formation which is about $200 \mathrm{~m}$ in thickness and is interpreted as a current or wave reworked banded iron formation (BIF), as suggested by the abundance of BIF intraclasts and sedimentary structures [6]-[8]. Talc has been reported in Langley 447 (Kuruman) and Topaz on the farms in the vicinity of Gravelotte as well as on farm Baviaans Krantz 474 in the Gordonia District of the Northern Cape Province. In the lower part of the Daniëlskuil and Kuruman Formations of the Asbestos Hills Subgroup, crocidolite deposits are found. Small crocidolite deposits were exploited on the farms Billinghurst 681, Crawley 682, Gathlose 548 and Groenwater 453. The Koegas crocidolite field spans from Griquatown to beyond Koegas, a total distance of $150 \mathrm{~km}$ and considered the oldest asbestos field in South Africa (Ehlers and Vorster [9]). Although the deposits of gem-quality tiger's eye in South Africa are very large, they occur only in the BIF of the Griqualand West Supergroup in the northern part of the Northern Cape Province. The crocidolite deposit is present from Prieska in the south to Kuruman in the north, a distance of $450 \mathrm{~km}$, and occurs in a range of hills field lies mainly in Griqualand West and extends northwards along a line from $50 \mathrm{~km}$ south of 


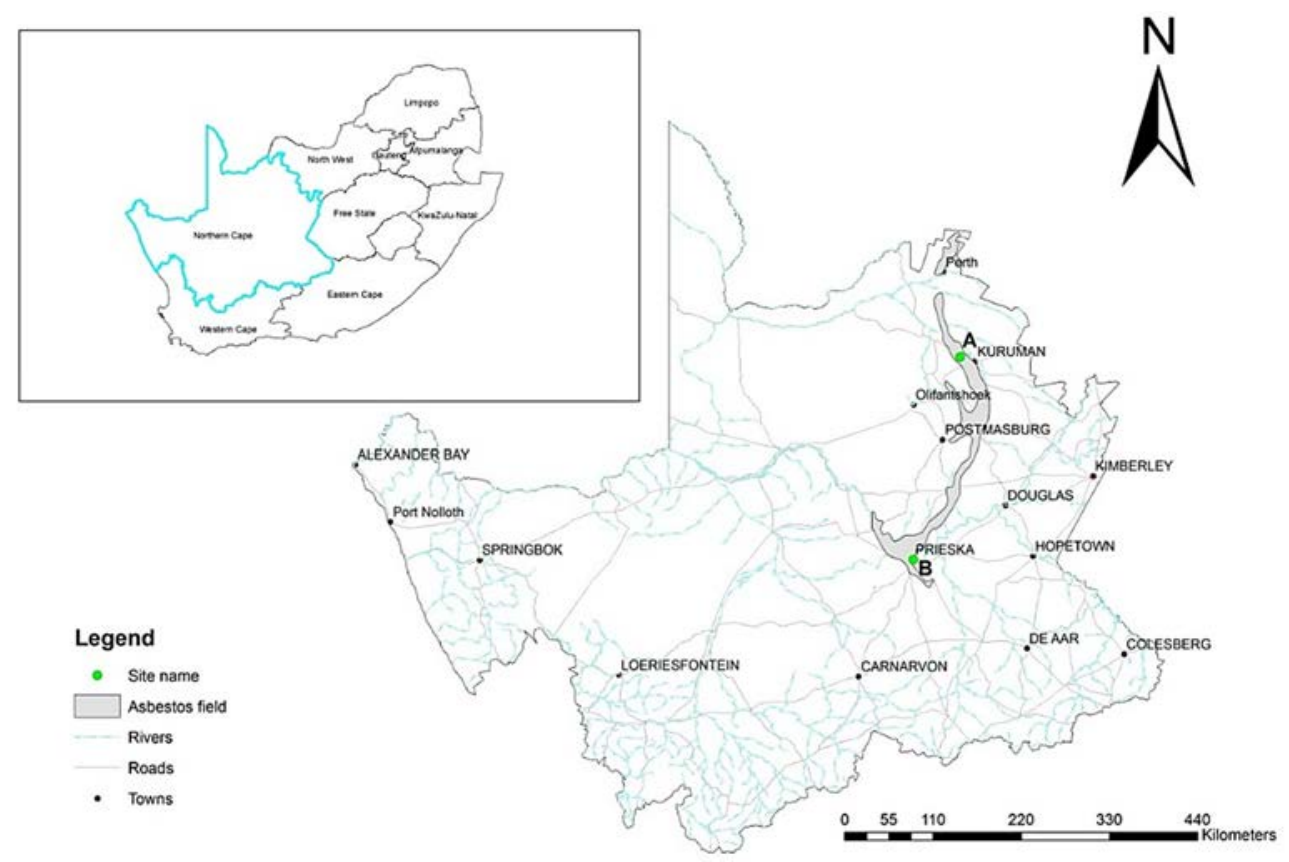

Figure 1: Locality map showing sampling sites and the crocidolite asbestos fields running from south of Prieska towards the Botswana border.

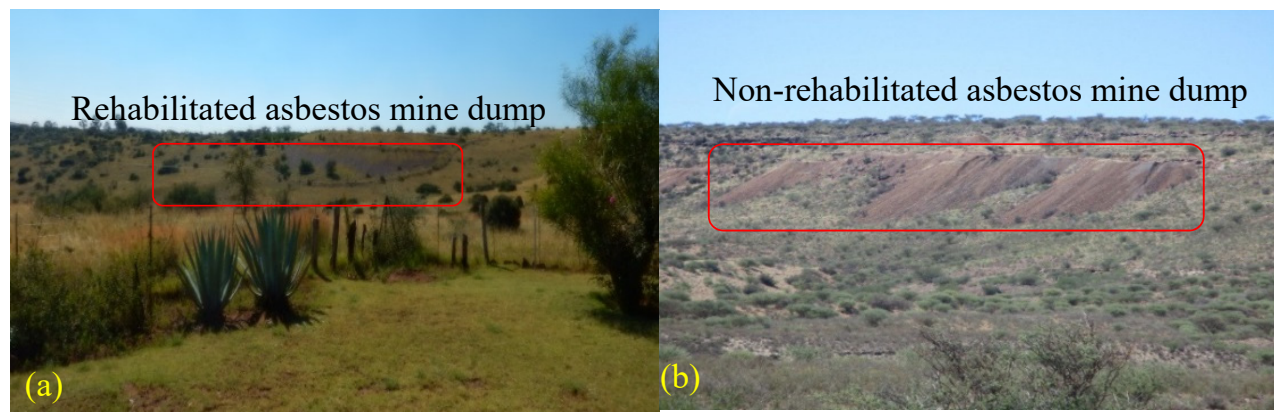

Figure 2: (a) Site A showing rehabilitated asbestos mine dump with vegetation growing naturally; and (b) Site B showing non-rehabilitated asbestos mine dump.

Prieska known as the Asbestos Hills in the south and the Kuruman Hills in the north (Fig. 1). The Cape crocidolite, on the Orange River, Griquatown and Kuruman, to its presently known northernmost occurrence in Botswana, approximately $40 \mathrm{~km}$ to the north of the South AfricaBotswana border, a distance of about $450 \mathrm{~km}$. The crocidolite is developed in banded ironstone of the Asbestos Hills Formation of the Griquatown Group. Anthophyllite and tremolite are found in xenoliths of serpentinite, gneiss and pyroxenite in the granite and schist of Swazian age in the Limpopo and central KwaZulu-Natal Provinces [9]. 


\subsection{Sampling methods}

The American Standard Test Method (ASTM) was used as a guideline to collect dustfall samples [10]. Two monitoring sites within human settlements that are near abandoned rehabilitated and non-rehabilitated asbestos mine dumps were selected. These monitoring sites were at least $5 \mathrm{~km}$ away from the abandoned asbestos mine dumps. Single dust monitoring bucket units were placed in secured yards, free from high buildings and trees (Fig. 3(a)). As can be seen from Fig. 3, the unit was exposed to collect dustfall for a period of 30 days and mounted on a $2 \mathrm{~m}$ stand to prevent interference from surface dust. It was half-filled with deionised or distilled water for the prevention of loss by wind. Dustfall samples were filtered and measured gravimetrically before being taken to the laboratory for characterisation (Fig. 4). Filter papers were weighed before and after to determine the mass of filtered samples for depositional rates. Trapped dust samples were collected indoors and outdoors (Fig. 3(b)) from photo frames, window frames, old furniture and roof tops using the sticky part of tape.

\subsection{Analytical methods}

Filtered samples collected from dustfall were allowed to dry out and left to stabilise overnight in a desiccator. Gravimetrical measurements were taken before the samples were submitted to the laboratory for characterisation. Mass concentrations were used to calculate dustfall or

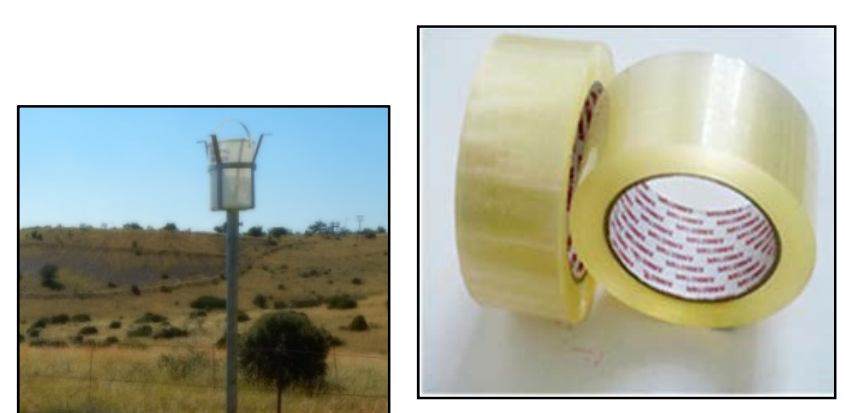

(b)

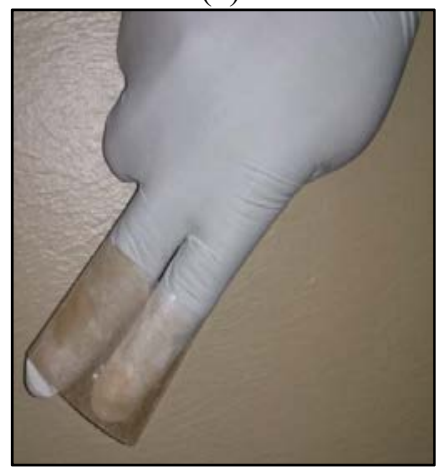

(d)

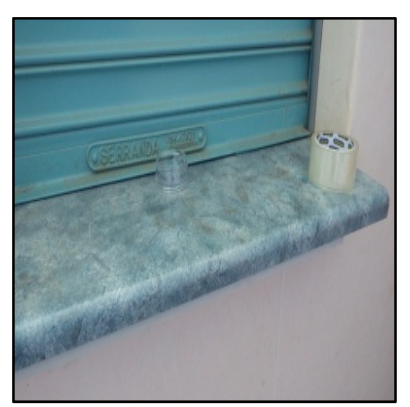

(c)

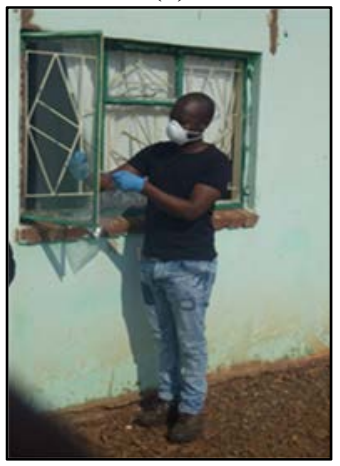

(e)

Figure 3: (a) A single dust monitoring unit within a $2 \mathrm{~km}$ radius from the rehabilitated asbestos mine dump; and (b)-(e) Collection of outdoor trapped dust. 

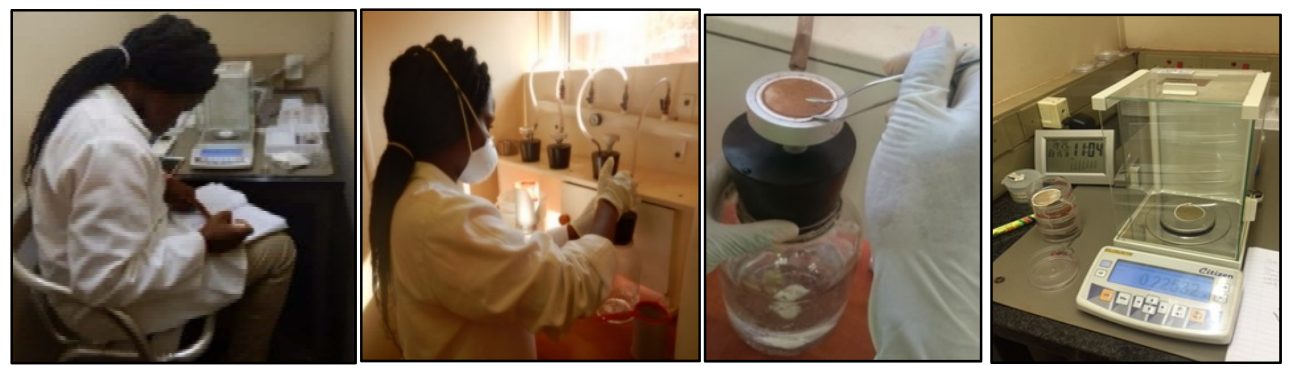

Figure 4: Filtration process of dustfall samples.

depositional rates and compared to the residential limit of $600 \mathrm{mg} / \mathrm{m}^{2} /$ day guided by South African National Dust Control Regulations (NDCR) [11]. The formula below was used for dustfall rate calculations expressed in milligrammes per square metres per 30 days period $\left(\mathrm{mg} / \mathrm{m}^{2} /\right.$ day $)$ :

$$
D=\frac{\mathrm{Wf}-\mathrm{W} b}{\mathrm{Ax30 \textrm {days }}}
$$

where:

$\mathrm{D}=$ the dustfall or depositional rate $\left(\mathrm{mg} / \mathrm{m}^{2} /\right.$ days $)$

$\mathrm{Wf}=$ the weight or mass of the filtered sample $(\mathrm{mg})$

$\mathrm{Wb}=$ the weight or mass of the blank filter (mg)

$\mathrm{A}=$ the collection area, the cross-sectional area of the inside diameter of the top of the container or bucket $\left(\mathrm{m}^{2}\right)$.

Both trapped dust and filtered samples were characterised by means of X-ray diffraction (XRD) to determine the mineralogical composition of the dumps. Measurements were performed using the BRUKER D8 ADVANCE diffractometer instrument with a $2.2 \mathrm{~kW} \mathrm{Cu}$ anode long fine focus tube [12]. The system is equipped with a LynxEye detector with a $3.7^{\circ}$ active area. Samples ran in step scan mode from 2 to $70^{\circ} 2 \theta \mathrm{CuK} \alpha(\lambda=1.54060)$ radiation at a speed of $0.02^{\circ} 2 \theta$ steps size $/ 3 \mathrm{sec}$ and generator settings of $40 \mathrm{kV}$ and $40 \mathrm{~mA}$. Phase identification was based on the BRUKER DIFFRAC plus - EVA evaluation program. Semiquantitative estimates of phase concentrations were determined using the reference intensity ratios and relative peak heights/areas of proportions.

The scanning electron microscopy with energy dispersive spectroscopy (SEM-EDS) technique was used to characterise mineralogical and morphological compositions. The morphological measurements include the grain size, shape, fibrous nature and type. SEMEDS technique confirms the mineralogical composition because the XRD technique has tendencies of mineral interferences and diffraction patterns overlapping. Characterisation was performed on a Leica 440 Stereoscan SEM with an INCA (OXFORD) EDS instrument wherein the system is equipped with an Oxford X-Max SDD detector with $20 \mathrm{~mm}^{2}$ active area and a resolution of about $128 \mathrm{eV}$ for $\mathrm{Mn} \mathrm{K}_{\alpha}(5895 \mathrm{eV})$ [12]. Analyses were done at $\sim 800-1000$ times magnification and the brightness/contrast settings adjusted to accentuate minerals of interest. Presentation of results was in the form of backscattered electron (BSE) images for each sample and the mineral chemistry was determined by means of spot analyses 
with the EDS. Counting time were set as $100 \mathrm{~s}$ and the probe current at $2 \mathrm{nA}$ with an accelerating voltage of $20 \mathrm{kV}$.

\section{RESULTS AND DISCUSSION}

\subsection{Dustfall or depositional rates}

The dustfall rates for both Sites A and B (Fig. 5) were within the accepted residential limit of $600 \mathrm{mg} / \mathrm{m}^{2} /$ day as stipulated by NDCR No. 827 of 2013. During the time of investigation, there were no mining activities taking place in the area. Site A recorded dustfall rates of below $200 \mathrm{mg} / \mathrm{m}^{2} /$ day in all the months. The high value of the dustfall rate at $473 \mathrm{mg} / \mathrm{m}^{2} /$ day recorded in July for Site B (Fig. 5) could be attributed to dry periods (i.e. the winter season) as the area experiences considerable windblown dust during these times. Meteorological parameters influence dustfall generation. Very low temperatures of $1.0^{\circ} \mathrm{C}$ (minimum) and $18.9^{\circ} \mathrm{C}$ (maximum) with no rainfall recorded at Site B during the month of July contributed to high dustfall rates (Table 1). Furthermore, an average wind speed of $2.3 \mathrm{~m} / \mathrm{s}$ that was below the threshold of $5 \mathrm{~m} / \mathrm{s}$ also contributed to high dustfall rates.

Low humidity reduces visibility and high humidity causes the generation of high dustfall rates. Site $\mathrm{A}$ is characterised by lower amounts of humidity ranging between $28.7 \%, 41.3 \%$ and $57.3 \%$. Consequently, the dustfall rates were very low. Site B had a substantial amount of humidity ranging between $61.2 \%, 68.0 \%$ and $76.4 \%$. The high amount of moisture content might be attributed to rainfall received in August 2016. Meteorological data extracted from the database of the South African Weather Services confirmed that the area experiences minimal or no rainfall during dry periods (Table 1).

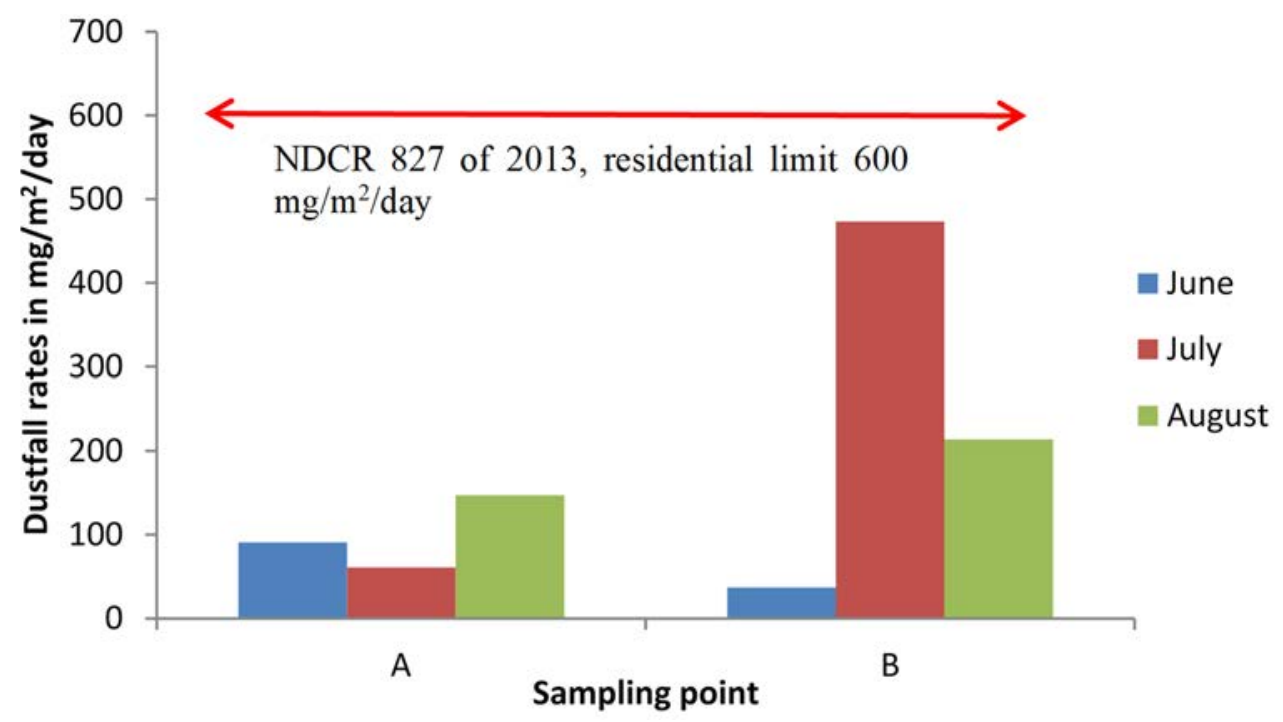

Figure 5: Dustfall rates in $\mathrm{mg} / \mathrm{m}^{2} /$ day collected during the dry periods of 2016. 
Table 1: Average meteorology parameters for Kuruman and Prieska towns in the Northern Province [13].

\begin{tabular}{|c|c|c|c|c|c|c|}
\hline \multirow[t]{2}{*}{ Site } & \multirow[t]{2}{*}{ Period } & \multicolumn{2}{|c|}{ Temperature $\left({ }^{\circ} \mathrm{C}\right)$} & \multirow{2}{*}{$\begin{array}{l}\text { Humidity } \\
(\%)\end{array}$} & \multirow{2}{*}{$\begin{array}{l}\text { Rainfal } \\
1(\mathrm{~mm})\end{array}$} & \multirow{2}{*}{$\begin{array}{l}\text { Wind speed } \\
(\mathrm{m} / \mathrm{s})\end{array}$} \\
\hline & & Maximum & Minimum & & & \\
\hline \multirow{3}{*}{$\begin{array}{l}\text { Kuruman } \\
\text { (Site A) }\end{array}$} & June-16 & 20.6 & 4.6 & 57.3 & 0.0 & 2.9 \\
\hline & July-16 & 20.5 & 3.0 & 41.3 & 0.0 & 3.0 \\
\hline & August-16 & 24.4 & 5.6 & 28.7 & 0.0 & 3.6 \\
\hline \multirow{3}{*}{$\begin{array}{l}\text { Prieska } \\
\text { (Site B) }\end{array}$} & June-16 & 21.0 & 2.7 & 76.4 & 0.0 & 1.7 \\
\hline & July-16 & 18.9 & 1.0 & 68.0 & 0.0 & 2.3 \\
\hline & August-16 & 24.2 & 2.9 & 61.2 & 1.6 & 2.0 \\
\hline
\end{tabular}

\subsection{X-ray diffraction}

Mineralogical composition identified by the XRD technique is presented in Table 2 . Amphibole $\left[\mathrm{Ca}_{2}(\mathrm{Fe}, \mathrm{Mg})_{5} \mathrm{Si}_{8} \mathrm{O}_{22}(\mathrm{OH})_{2}\right]$ asbestos mineral group was detected in Sites A and B with dominance in Site A. During the months of June and August 2016, Site A recorded high concentrations of amphibole at $40 \%$ and $37 \%$ respectively and $9 \%$ was recorded in July. Site $\mathrm{B}$ reported lower concentrations of amphibole at $6 \%$ that was only reported in the month of August. Detection of amphibole was expected for Sites A and B as this conforms to the crocidolite deposits documented by Ehlers and Vorster [9] within the area and through physical identification or field observation of bluish asbestos fibres towards the dumps.

Detection of kaolinite $\left[\mathrm{Al}_{2} \mathrm{SiO}(\mathrm{OH})_{4}\right] /$ clinochlore/serpentine $\left[\mathrm{Mg}_{3} \mathrm{SiO}_{5}(\mathrm{OH})_{4}\right]$ minerals from both Sites A and B by XRD could be attributed to the presence of other mineral interferences and diffraction patterns overlapping. A hydrous magnesium silicate mineral talc $\left[\mathrm{Mg}_{3} \mathrm{Si}_{3} \mathrm{O}_{10}(\mathrm{OH})_{3}\right]$ occurs in both platy and fibrous forms. This fine-grained mineral is likely to occur in coexistence with asbestos minerals [14], [15]. Silicate mineral talc $\left[\mathrm{Mg}_{3} \mathrm{Si}_{3} \mathrm{O}_{10}(\mathrm{OH})_{3}\right]$ was detected in both Sites $\mathrm{A}$ and $\mathrm{B}$. Lutgens and Tarbuck [16] documented that the earth's crust mainly constitutes oxygen $\left(\mathrm{O}_{2}\right)$ and silicon $(\mathrm{Si})$ which make up the

Table 2: Common minerals detected in filtered dust samples determined by XRD and expressed in $\mathrm{wt} \%$.

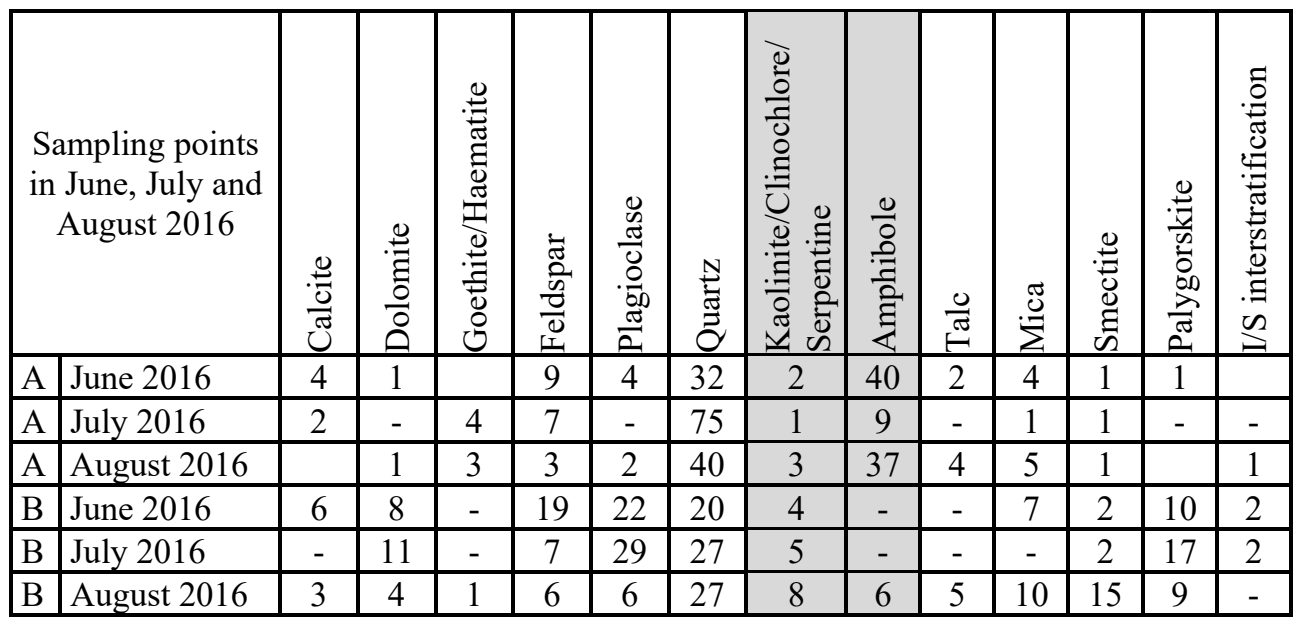


silicate mineral quartz $\left(\mathrm{SiO}_{2}\right)$. A high percentage of the silicate mineral quartz was detected in all sites. Other silicate minerals that were detected include mica and plagioclase. Nonsilicate minerals such as calcite $\left(\mathrm{CaCO}_{3}\right)$ and haematite $\left(\mathrm{Fe}_{2} \mathrm{O}_{3}\right)$ were also detected in trace levels.

\subsection{Scanning electron microscope with energy dispersive spectroscopy (SEM-EDS)}

SEM-EDS results are depicted in Figs 6-8. Partial exposure or the submicron size of the fibre affects the correspondence of the actual size. In the case of fragmentation and bundling of fibres, usually the dimensions of the longest and thinnest (smallest diameter) that might potentially be produced is given. Results of trapped dust samples collected from Site A indoors from the window frame and outdoors on the garden table are shown on the backscattered electron (BSE) image (Fig. 6). Triangular to semi-triangular shape quartz $\left(\mathrm{SiO}_{2}\right)$ particles were observed on images of samples collected indoors and outdoors. Semispherical with aerodynamic diameter mica particles were detected on the outdoor image. Non-silicate minerals such as haematite $\left(\mathrm{Fe}_{2} \mathrm{O}_{3}\right)$ were also detected. Circular to semi-circular particles of zircon $\left(\mathrm{ZrSiO}_{4}\right)$ were observed on the BSE image of the outdoor sample. Neither amphibole nor serpentine asbestos minerals were detected from both indoor and outdoor trapped dust samples from Site A.

BSE images (Fig. 7) below show identified amphibole minerals detected from the nonrehabilitated Site B from indoor cupboard (left) and outdoor main switch box (right). Scattered particles with different shapes were observed on both images. As revealed from XRD results, SEM analyses also confirm the presence of amphibole minerals in this human settlement near the non-rehabilitated asbestos dump.

Of interest were the aerodynamic diameters ranging from $\sim 1 \mu \mathrm{m}$ to $\sim 50 \mu \mathrm{m}$ of fibrous particles of amphibole minerals from Fig. 7 (left), the indoor trapped dust sample. A straight amphibole fibrous particle $(\sim 200 \mu \mathrm{m})$ was detected from a trapped outdoor dust sample (Fig. 7 , right). Other silicate minerals observed includes talc, feldspar, quartz and plagioclase. A non-silicate straight chlorine particle $(\sim 80 \mu \mathrm{m})$ was identified in the indoor trapped dust (Fig. 7 , left) from the cupboard surfaces. Calcite, which is also a non-silicate mineral, was identified in coexistence with the silicate mineral quartz.

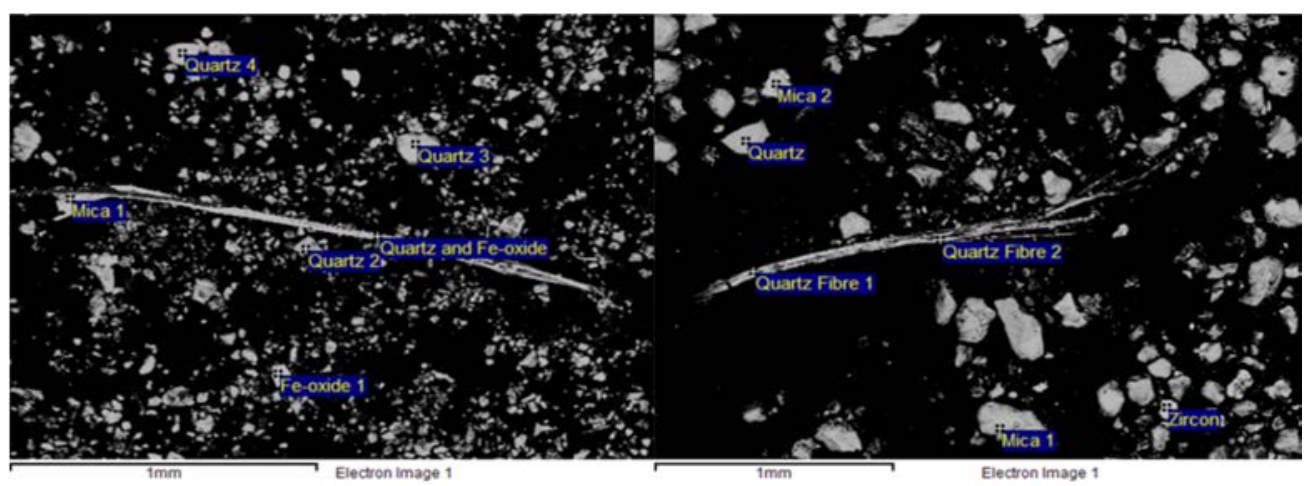

Figure 6: BSE image for trapped dust sample from rehabilitated Site A. Left, window frame indoor and right, garden table outdoor. 

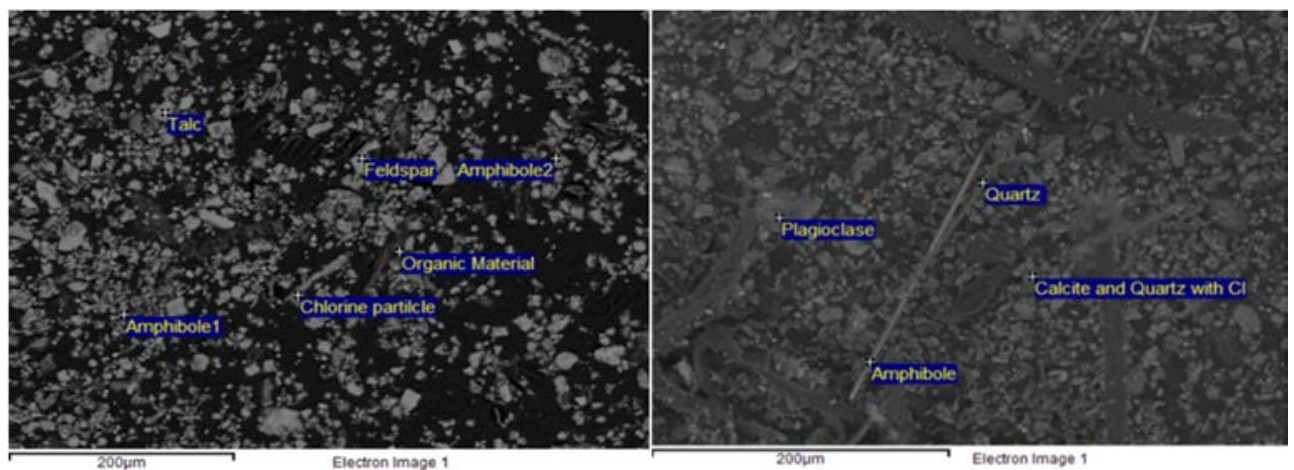

Figure 7: BSE images for trapped dust sample from non-rehabilitated Site B. Left, indoor cupboard surfaces and right, outdoor main switch box surfaces.
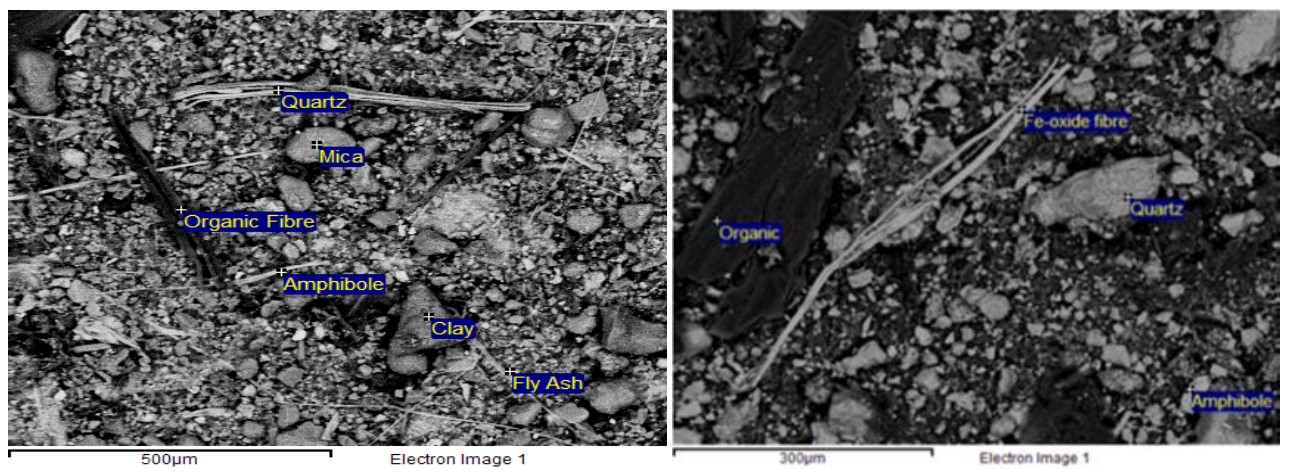

Figure 8: Micrograph SEM of filtered samples from Sites A and B respectively.

Filtered dust samples from Sites A and B are represented as BSE or micrograph images (Fig. 8). Site A is characterised by various silicate and non-silicate minerals of different particles that are fibrous. Nearly straight fibrous amphibole minerals in the region of 150 $200 \mu \mathrm{m}$ were detected and identified by XRD. A semi-spherical silicate mica particle was clearly observed through electron microscopy. A clear semi-triangular clay particle was identified on the image of Site A. Other silicate minerals such as quartz were also detected. Aerodynamic diameter of fly ash, which could be attributed to industrial activities, was detected as well depicting straight spongy like organic fibres of $\sim 400-450 \mu \mathrm{m}$.

Site B shows different shapes, grain sizes and types of minerals. Semi-triangular silicate mineral quartz $\left(\mathrm{SiO}_{2}\right)$ of $\sim 180 \mu \mathrm{m}$ was clearly identified on the image of Site $\mathrm{B}$. The site is also characterised by semi-rectangular and fibrous particles of $\sim 60 \mu \mathrm{m}$ of amphibole minerals. A large spongy like particle of organic fibre with a diameter of $\sim 400 \mu \mathrm{m}$ was also identified from Site B.

\section{CONCLUSIONS}

This study was conducted to characterize trapped dust and dustfall samples within human settlements Furthermore, comparison of the presence of asbestos fibres was done for both the 
rehabilitated (Site A) and non-rehabilitated (Site B) mine dumps. Dustfall rates of both Sites A and B were within residential limits as stipulated by NDCR 827 of 2013. Dustfall rates do not stipulate that there will be more or less asbestos fibres; the ASTM was used for screening purposes. Metereological parameters influence dustfall rates. Significant levels of amphibole $\left[\mathrm{Ca}_{2}(\mathrm{Fe}, \mathrm{Mg})_{5} \mathrm{Si}_{8} \mathrm{O}_{22}(\mathrm{OH})_{2}\right]$ asbestos minerals were confirmed by SEM-EDS and XRD data of both Sites A and B.

The following conclusions have been drawn with respect to the rehabilitated mine dump (Site A):

- Run-off and strong winds are factors contributing to the deterioration of rehabilitated asbestos mine dumps.

- XRD results for filtered samples revealed high concentrations of asbestos minerals present on the rehabilitated mine dump (Site A) compared to the non-rehabilitated mine dump (Site B). This could be associated with a lack of maintenance, run-off and strong winds.

- Detection of amphibole minerals on filtered samples for Site A was further confirmed by SEM-EDS analysis.

- There were no asbestos minerals detected from indoor and outdoor trapped dust samples.

Conclusions drawn with respect to the non-rehabilitated dump (Site B):

- Non-rehabilitated asbestos mine dumps are a major source of airborne fibre exposure.

- Continuous exposure of asbestos fibres can lead to diseases such as asbestosis, mesothelioma and lung cancer. Other diseases include cancer of the liver, brain and mammary glands.

- Samples collected to represent the non-rehabilitated asbestos mine dump at Site B also showed potential amounts of asbestos minerals.

- This finding was concluded based on both XRD and SEM-EDS analyses.

- Amphibole mineral was detected by XRD from filtered samples taken during the month of August.

- Both indoor and outdoor trapped dust samples revealed the presence of amphibole fibres.

Furthermore, silicate minerals such as quartz, talc, mica and plagioclase were detected from mineralogical compounds of both trapped and filtered samples on Sites A and B. Calcite and haematite non-silicate minerals were also detected on both sites. The results of this pilot study confirm the continued presence of asbestos fibres within residential areas despite asbestos mining being banned in South Africa, which is a major concern for human health.

\section{RECOMMENDATION}

Monitoring and maintenance of the abandoned asbestos mine dump at Site A is highly recommended to maintain the integrity of rehabilitation. Urgent rehabilitation of mine dumps at Site B is needed as exposure to asbestos continues to pose health risks to people residing near the dumps. The rehabilitation programme should also include a proper investigation taking into consideration issues such as droughts, veld fires and windy seasons. Rehabilitation should include the proper sealing of mine openings that were identified during fieldwork with slab concrete and visible signage or landmarks. In addition, backfilling and 
levelling can be done using local materials as they are readily available and less expensive. As a short-term remedial solution, it is recommended to conduct public awareness sessions educating the communities about the risks associated with asbestos contamination and advising affected parties to wear respiratory dust masks when exposed to dust. Furthermore, consultation with medical experts (i.e. doctors and nurses) at clinics or hospitals for diagnosis will also be helpful for screening purposes. Future work will involve continuous monitoring and measurement of dustfall rates within human settlement that are near asbestos dumps. There is a need to determine the asbestos fibrous pollutants levels in the environmental samples using regulatory asbestos fibre count method.

\section{ACKNOWLEDGEMENTS}

The authors would like to thank the Department of Mineral Resources for funding this project. The Council for Geoscience is acknowledged for the XRD and SEM-EDS analyses. Andries Somo and Siphilile Mhlongo are acknowledged for their assistance during fieldwork.

\section{REFERENCES}

[1] Hart, H.P., Asbestos in South Africa. Journal of the South African Institute of Mining and Metallurgy, 88(6), pp. 185-198, 1988.

[2] McCulloch, J., Surviving blue asbestos: Mining and occupational disease in South Africa and Australia. Transformation, 65, pp. 65-93, ISSN 0258-7696, 2007.

[3] Wagner, J.C., Some pathological aspects of asbestosis in the Union of South Africa. Proceedings of the Pneumoconiosis Conference, Johannesburg, 1959 (A.J. Orenstein, ed.), J. \& A. Churchill, London, pp. 373-382, 1960.

[4] Felix, M.A., Leger, J.P. \& Ehrlich, R.J., Three minerals, three epidemics. Asbestos mining and diseases in South Africa, pp. 265-286, 1994.

[5] Moore, J.M., Tsikos, H. \& Polteau, S., Deconstruction the Transvaal Supergroup, South Africa. Implications for Palaeoproterozoic, palaeoclimate models. African Earth Sciences, 33, pp. 437-444, 2001.

[6] Beukes, N.J., Paleoenvironmental setting of iron formation in the depositional basin of the Transvaal Supergroup, South Africa. Iron-formation: Facts and Problems, eds A.F. Trendall \& R.C. Morris, Elsevier: Amsterdam, pp. 131-210, 1983.

[7] Klein, C. \& Beukes, N.J., Geochemistry and sedimentology of facies transition from limestone to iron formation deposition in the early Proterozoic Transvaal Supergroup, South Africa. Economic Geology, 84, pp. 1733-1774.

[8] Beukes, N.J. \& Klein, C., Geochemistry and sedimentology of the facies transition from the micro banded to granular iron-formation in the Early Proterozoic Transvaal Supergroup, South Africa. Precambrian Research, 47, pp. 99-139, 1990.

[9] Ehlers, D.L. \& Vorster, C.J., Asbestos, pp. 68-75. In: Wilson, M.G.C. \& Anhaeusser, C.R., (eds). The Mineral Resources of South Africa. Handbook, Council for Geoscience, 16, p. 740, 1998.

[10] ASTM International D1739-1970, Standard Test Method for Collection and Measurement of Dustfall (Settleable Particulate Matter), West Conshohocken, Pennsylvania, PA, doi: 10.1520/D1739-98 R10, 1970.

[11] South African National Dust Control Regulations (SANDCR), No. 827.2013.

[12] Anatasova, M. The Scanning Electron Microscopy Mineralogy Laboratory Method, Council for Geoscience, 2016.

[13] South African Weather Weather Services, www.weathersa.co.za, 2016.

[14] Moja, S.J., Kwata, M.G., Sebesho, L.M., Masindi, K.G. \& Mtunzi, F., Characterisation of surface and trapped dust samples around human settlements that are in the vicinity 
of old mine tailings in Mpumalanga Province, South Africa. Journal of Earth Science \& Climate Change, 7(7), pp. 1-7, 2016.

[15] Rohl, A.N., Asbestos in talc. Environmental Health Perspective, 9, pp. 129-132, 1974.

[16] Lutgens, F.K. \& Tarbuck, E.J., Essentials of Geology. WW Norton Publishers, 2000. 